\author{
Лясота A. $\epsilon$. \\ кандидат політичних наук, доцент, \\ доцент каффедри політологї \\ Дніпровського національного університету ілені Олеся Гончара
}

\title{
ФУНКЦІОНАЛЬНІ АСПЕКТИ ПОЛІТИЧНИХ ІНСТИТУТІВ У КОНТЕКСТІ ОРГАНІЗАЦІЇ ПОЛІТИЧНОГО ПОРЯДКУ
}

\begin{abstract}
Анотація. Стаття присвячена актуальній проблемі інституалізації та організації політичного порядку в демократичних суспільствах. На думку автора, утворення незалежної України, подальше національне та державне будівництво зіткнулося із проблемами низького функціонального потенціалу інституцій, їхньої нездатності вирішити нагальні соціальні, економічні та стратегічні проблеми; чи відсутності інституцій загалом. Натепер питання конструювання ефективних, стійких політичних інституцій, загалом, не вирішено. Автор робить висновок, що переосмислення теоретичної наукової та експертної думки, аналіз практичного прояву інститутів у політичній реальності $є$ важливою складовою частиною підвищення можливостей та потенціалу інститутів в Україні. Даний процес потребує вироблення та застосування ефективних аналітичних інструментів.
\end{abstract}

Актуальність роботи полягає у формулюванні нових наукових поглядів на прояв інституціональних аспектів політичної сфери. Оскільки інституціональна складова частина політичної системи являє собою системоутворюючий контекст функціонування соціуму та продукування політичних процесів актуалізується: по-перше, питання дослідження еволюції теоретичного базису інституціональної теорії; по-друге, конкретизація прикладних аспектів інституціоналізму, формування яких зумовлено еволюцією інституціонального середовища.

Актуалізації інституціональних аспектів політичної сфери в останні декілька десятиліть, серед іншого, сприяла необхідність конструювання інновацій, концепції та моделей оптимізації, реформування політичних систем новоутворених демократій. Інтелектуальне проєктування в політичній сфері стало безпосередньо пов'язано із процесом інституційного дизайну та будівництва. У дослідницькому полі науковців, експертів і політиків постало питання формування ефективної, динамічної, орієнтованої на демократичний політичний процес системи, здатної адаптуватися до мінливих умов зовнішнього середовища.

Ключові слова: політичні інститути, політичний порядок, політична комунікація.

Постановка проблеми. Починаючи розкриття характерологічних ознак і параметрів політичних інститутів, у межах старого та нового інституціоналізму, потрібно зазначити, що обидва підходи (з різних методологічних позицій) визнають регулятивну, відтворюючу та впорядковуючу роль інститутів, у межах політичного середовища. Даний вимір функціонування політичних інститутів також потребує глибшого аналізу та конкретизації. Розкриття відповідних «функціональних змінних» інститутів пояснюється амбівалентністю їхньої ролі та внутрішньої сутності, у межах соціальної системи: 3 одного боку, інститути є інструментом конструювання соціальної реальності; із другого боку, інститути іманентно виступають кінцевим результатом цієї реальності - соціальна інженерія, сприяючи трансформації навколишнього середовища, продукує нові ідеї, цінності й інститути, що швидко набувають потенціалу впорядкування соціальної реальності (правил гри та моделей поведінки).

Мета статті - дослідження ролі та потенціалу інститутів в контексті структуризації й організації політичного порядку, а також розгляд коммунікативного прояву функціонування політичних інститутів.

Виклад основного матеріалу дослідження. У процесі розгляду сутності політичного порядку першочергово варто конкретизувати положення соціального порядку. Найбільш грунтовно питання розроблення категорії соціального порядку було розглянуто Т. Парсонсом. Соціальний порядок, на думку вченого, не є випадковим результатом взаємодії соціальних агентів, що протистоїть хаотизації соціального середовища. Він представляється як стійкий, усеосяжний у межах соціальної системи та відтворюючий у часі-просторі. Усе ж варто наголосити, що натепер у результаті еволюції соціальної системи, зміни іiї процесуальної динаміки, організаційної складності та навіть просторових характеристик соціальних порядок складається із цілої низки локальних моделей соціального порядку, яким притаманні власні, специфічні характеристики [1, с. 25]. Не акцентуючи увагу на типології масштабності соціального порядку, варто все ж додати, що універсальними для будь-яких його типів $€$ мінливий ансамбль відносин, що продукують у навколишнє середовище суспільні явища, колективні інтеракції, він завжди відзначається лабільністю, локальністю та динамічністю [4, с. 45].

Інститути безпосередньо стосуються соціального порядку: саме вони є нормативною й організаційною складовою частиною його забезпечення. Сукупність соціальних порядків на мікрорівні демонструє певні специфічні ціннісні моделі поведінки, інтерації, правила взаємодії, які так чи інакше стають легітимною частиною загального порядку. Узагалі, порядок будь-якого рівня є відображенням інституційної реальності того чи іншого політичного простору. Інституціональна реальність іманентно залежить від рівня розвитку соціальної інженерії: прикладної галузі, направленої на конструювання соціальної реальності, інституційного будівництва, продукування ідей, смислів, інновацій. Рівень розвитку соціальної інженерії контекстуально залежить від рівня розвитку соціального капіталу, партисипаторних 
традицій, соціокультурних/історичних аспектів функціонування соціальної системи. На думку А. Гриценко, традиції, соціокультурні чинники соціально-політичної сфери не зникають у часовому вимірі. Володіючи істотною стійкістю, лабільністю, вони трансформуються, залишаючись домінантним елементом інституціональної архітектоніки. Але існує можливість поступової втрати ними власної ролі, після чого на їхнє місце приходять різного роду ієрархічні моделі, що знаходять відображення в різних формах статусно-рольових позицій [7, с. 36].

А. Зайцев під інституційним дизайном, у політичній площині, розуміє сукупність, внутрішне поєднання, структурування інститутів публічної політики, за якого вони загалом являють собою дещо цілісне та єдине, інакше кажучи, систему інститутів. Процес інституційного дизайну (який варто розуміти як процес трансформації, видозміни традиційних інститутів політичної системи) зазвичай проходить три базові фази: легалізації (організаційно-правове формування інституту), легітимізації, соціалізації й інтеріоризації (відповідність нормам демократії, їх адаптації в суспільній свідомості) та зростання ефективності інституту (організаційні та самоорганізаційні процеси) [9, с. 150]. Тобто процес інституціоналізації $є$ закономірним процесом трансформації, реорганізації та видозміни соціального порядку.

П. Штомпка, розмірковуючи про процес інституціоналізації нормативних параметрів структури певного соціального інституту, робить акцент на перегрупуванні комплексу соціальних норм, правил, ціннісних комплексів, що зосереджені довкола функцій, які мають соціально значущий потенціал, - виробництва, політико-управлінської, комунікативної. Ключовою, цілком зрозуміло, є функція політичного управління, оскільки воно $€$ «організаційним центром» продукування інструментів і механізмів забезпечення політичного порядку. Політичний порядок має нормативний, регулюючий та контролюючий потенціал у політичній сфері. Також політичний порядок забезпечує організацію політичного процесу та політичного життя, які засновуються на ієрархії, розподілі статусно-рольових позицій, координації та підпорядкуванні. Ще одна особливість політичного порядку -прагнення окремих акторів політичного життя зробити політичний порядок відповідним власним цілям, прагненням і мотивам. Якщо розглядати інституційне середовище як інтегровану сукупність формальних і неформальних норм та правил гри, логіка дії окремих агентів цілком зрозуміла: боротьба за статусні позиції та ресурси часто рівнозначна можливості корегувати політичний порядок, змінюючи чи корегуючи правила гри $[4$, с. 46].

Ще одним інституційним проявом соціального та політичного порядку є наявність у суспільстві так званих «інституційних дискурсів», що функціонують згідно 3 обмеженнями, вимогами, характеризуються структурною впорядкованістю та рівновагою. Головним аспектом структурної впорядкованості є поведінкова й організаційна ритуалізованість, символізм. Продукування знань, традиційних аспектів культури в межах інституційного дискурсу суто технічно здійснюється за допомогою міфів, ритуалів, логотипів, знаково-символічних аспектів. Сутність символізму, на думку Р. Водака, ставить за мету «конвертувати» гостроту конфліктів, суперечностей між учасниками інституційного спілкування чи будь-яких чинників, здатних істотно порушити дискурс. Інституційний дискурс $€$ носієм не тільки ритуалізованних соціокультурних цінностей, але і механізмів відтворення суспільного порядку. Інше питання, що контекстуально постає в даній ситуації, - підбір комунікативних інструментів, які здатні амортизувати флуктуаційні чинники, у межах соціальної системи [12, с. 196]. Дане питання залежить від специфіки соціокультурного середовища, нормативно-ціннісної системи. Логіка функціонування інститутів починає сприяти відтворенню соціального та політичного порядку. Контекстуально повертаючись до питання плюралізації політичного порядку, варто згадати, що цей процес зумовлений фрагментацією соціальної дійсності, коли певна сфера упорядкованих феноменів і явищ іманентно відтворюється. Роль топосу контекстуально полягає в дискретному прояві континууму соціальних відносин, що конструюють локальний соціальний порядок. Джерелом базових суспільниї відносин $є$ певні поведінкові моделі, що сформувалися на початку формування людських спільнот, відіграли істотну роль у галузі організації соціальної системи [4, с. 43]. У принципі сукупність соціальних порядків локального рівня роблять інституційний дискурс внутрішньо неоднорідним, структурованим. 3 іншого боку, ця структурованість виправдовує саме його існування - створити сприятливе для відтворення соціального порядку комунікативне середовище, на рівні цілої соціальної системи.

Далі логіка нашого дослідження передбачає розгляд коммунікативного прояву функціонування політичних інститутів, а саме управлінського, дискурсивного та символічного вимірів.

Важливим атрибутом, що об'єднує інститути різного порядку, $є$ комунікативна складова частина, що, з одного боку, $€$ інструментальною характеристикою реалізації інститутами власних функцій; методом передачі інформації між самими інститутами та соціальними агентами. Отже, інститути, які володіють істотним комунікативним потенціалом, забезпечують реалізацію управлінської, дискурсивної та символічної складових частин політичного життя.

Комунікативна функція інститутів надає можливість передавати від покоління до покоління накопиченні знання, навички, практики, норми та правила. Іншим проявом комунікативної функції інститутів $€$ необхідність інформаційного забезпечення, важливого для соціальних агентів, у процесі ухвалення останніми раціональних рішень. Також варто зазначити, що всі інститути прагнуть до набуття певних символів, які концентровано будуть виражати сутність функціонування окремо взятого інституту (герб, прапор - у випадку держави; розп'яття, півмісяць - у випадку релігійних інститутів) [8, с. 51-52]. Символічного характеру контекстуально можуть набувати навіть об'єкти природного ландшафту та соціальної інфраструктури.

К. Дойч у своій роботі «Нерви управління: модель політичної комунікації та контролю» сформував інформаційно-кібернетичну модель політичної системи, наголошуючи на інформаційно-комунікативному характері останньої. За моделлю К. Дойча, уряд суто технічно мобілізує політичну систему шляхом регулювання, контролю та передачі інформаційних потоків, комунікативної взаємодії системи 
та середовища, а також окремих комплексів усередині самої системи. Виробництво й обмін «інформаційним продуктом» у межах політичної системи забезпечує політичне керівництво, для якого інформація є необхідною складовою частиною ухвалення політичних рішень. Державні актори, використовуючи наявну в них політичну інформацію, керують власними політичними організаціями та проєктами. Функціонування політичної системи, на думку К. Дойча, контекстуально залежить від якості та постійності інформаційного обміну. Інститути та механізми влади контролюються інформаційною елітою - дейтократією [5, с. 75]. Політичне управління, під таким кутом, виступає своєрідною формою регулювання суспільно-політичних процесів i відносин за допомогою інформаційно-комунікативної мережі. Ухвалення політичних рішень залежить від якості процесу обміну інформації. На передній план виступають трансакційні витрати на отримання певної інформації, необхідної в галузі управління.

Польський науковець Т. Гобан-Клас у своїй праці «Засоби масової комунікації і масова комунікація» розглядав регулюючий вплив комунікації (за допомогою знаків і символів) на людей. Іншим проявом комунікації, на думку вченого, є об'єднання індивідів і груп у межах однієї соціальної спільноти (за допомогою мовної та знаково-символічної системи). Комунікація як розподіл цілей і завдань, що відображають прагнення всіх членів соціальної спільноти. Функцію вищого порядку, яку виконує комунікація як складова частина суспільного процесу, що відображає групові норми, здійснює громадський контроль (шляхом інформування про обмежувальні рамки), розподіляє статусно-рольові позиції соціальних агентів та координує їх зусилля [14, с. 180]. Відповідно до інтерпретації Т. Гобан-Класа, можна порівняти ролі та функції інститутів із практичними завданнями, виконуваними комунікативною структурою: контекстуально їх можна вважати синонімічними. Але комунікація є складовою частиною певної інституціоналізованої моделі взаємодії, тому є підпорядкованою складовою частиною функціонування інститутів, хоча і першочерговою.

Р. Шварцерберг політичну комунікацію визначає як процес інформації від однієї складової частини політичної чи соціальної системи (державних і політичних інститутів) до іншої: циркуляція інформаційних потоків між індивідами та групами всіх рівнів. Л. Пай підкреслював, що політична комунікації передбачає не однобічну спрямованість сигналів від еліт до маси, а широкий діапазон формальних і неформальних комунікаційних процесів у межах соціальної системи, що істотно впливають на політичну сферу. Політичне життя та політичний процес неможливі без усталених, упорядкованих методів і технології здійснення політичної комунікації [6, с. 82]. Отже, виходячи 3 теоретичних припущень обох учених, можна дійти таких висновків: комунікація забезпечує життєздатність політичної та соціальної систем, становить функціональну складову частину інститутів; як інститути комунікативної практики поділяються на формальні та неформальні.

Рівень невпевненості, що часто існує в межах соціальної та політичної систем, змінює вектор дії для раціональних індивідів. Відповідна невизначеність політичної ситуації $€$ первинним чинником із визначання стратегії політичних акторів і еліти. Високий чи низький ступені невизначеності середовища для конкуренції політичних еліт за владу, на рівні $з$ іншою інституціоналізованою організацією, соціальними мережами чи політичними партіями, призводить до специфічної форми бюрократичної організації. Рівень невизначеності змінює напрям дії раціональних акторів $[11$, c. 170]. Питання невизначеності ситуативно пов'язано 3 недостатньою інформаційною забезпеченістю для ухвалення рішення.

Натепер, у результаті еволюції соціальної системи процесу інституціоналізації піддано різноманітні моделі та формати комунікації між агентами політичного процесу. Але проблема низької ефективності організаційних і нормативних структур все ще залишається вкрай актуальною. За визначенням Е. Стриганкової, комунікативна практика розглядається як свідома, ціннісна, інтенціональна та соціально регламентована діяльність, що орієнтована на передачу соціально значущої інформації, структурована в часі та просторі, є спеціально організованою і відзначається постійним відтворенням комунікації різного рівня. Такий підхід характеризується наявністю двох ключових положень, що потребують уточнення та конкретизації: свідома активність індивідів, що залежить від неявної підсвідомої складової частини; комунікативні практики у процесі свого постійного відтворення часто схиляються до істотного переформатування власної внутрішньої структури, для подальшого відтворення в нових умовах [3, с. 126].

На думку вітчизняних науковців, як приклад можна навести інституційні практики, які забезпечують політичний порядок і можуть відтворюватися у вигляді неформальних регуляторів політичної комунікації. У разі формалізації відповідні інституційні практики стають частиною політичної системи. Конкретизація характерологічних параметрів політичної комунікації в заданих координатах дозволяє зосередитися на вихідних причинах кризових явищ і механізмах їх подолання, відійти від стереотипних уявлень щодо іiі змістовної сутності [3, с. 127].

Іншим полем для дослідження взаємозв'язку інституціональності та політичних комунікації є політичний дискурс. Під дискурсивним аналізом розуміють інтегральну сферу дослідження мовного спілкування з погляду форми, функцій, ситуативної соціокультурної зумовленості. Згідно 3 німецькою традицією дискурсивного аналізу, під дискурсом розуміється сукупність мовних інтеракцій у соціокультурному й історичному контекстах, у яких відтворюються колективне знання, мислення й орієнтації соціальних груп [13, c. $174-175]$.

Багатоаспектність і складність політичного дискурсу відповідає логіці диференційованого соціального простору: інституціональність - від обговорення політики на рівні мікрогрупи до складних міжурядових/міжінституціональних переговорів; суб'єктно-адресні відносини (диференціація моделей поведінки за варіативністю статусно-рольових позицій у суспільстві); соціокультурна диференціація, що пов'язана 3 неоднорідністю групових поведінкових норм, у контексті ментальної, культурно-ціннісної орієнтації, що приводить до формування локальних політичних соціолективів; подієва локалізація - диференціація жанрів за їх співвіднесеністю зі складними комунікативними 
подіями політичного дискурсу; ступінь прототипності маргінальність у польовій структурі дискурсу. До прототипних належать першочергові, інституціоналізовані жанри, які повною мірою відповідають основній інтенції політичного дискурсу - боротьбі за владу: парламентським дебатам, боротьбі за владу тощо [13, с. 175-176].

Теоретичні передумови дискурсивної («деліберативної») моделі демократії було концептуально оформленні ще Дж. Дьюї, на думку якого загальне голосування та правління більшості є лише початковим проявом демократії, яка, на думку мислителя, повинна передбачати дискусію, відкритість і публічність. Отже, головне завдання суспільства полягає у створенні сприятливого для дебатів, дискусій і консультацій середовища. Ю. Хабермас, по суті, теоретично оформив злиття дискурсу та деліберації. Саму ж деліберативну модель у подальшому почали називати дискурсивною [10, с. 30]. Конкретизуючи взаємозв'язок дискурсу та політичних інститутів, варто зазначити такі положення: розвиток інституційного середовища напряму залежить від рівня відкритості комунікативної мережі; громадське суспільство, яке передбачає публічність, відкритість і дискусію, є інститутом забезпечення горизонтальності політичної комунікації, яка, у свою чергу, прямо й опосередковано формує ефективне інституційне середовище.

Досліджуючи контекст управління суспільством за допомогою комунікативних інструментів і механізмів, окремо варто звернути увагу на символічні аспекти політичної сфери, цінність яких у контексті інституційних досліджень полягає в інформаційно-комунікативному потенціалі інститутів взагалі. На думку Ш. Айзенштадта, будь-яке суспільство має реальні та символічні події в історичному минулому. Сукупність відповідних елементів (фізичних і метафізичних) формує загальні та конкретні контури колективної ідентичності. Традиційне світосприйняття слугує визначником меж та мірою законності (легітимності) інноваційного розвитку та прогресистських процесів, ініційованих політичною елітою [11, с. 268].

Ф. Тенніс і Г. Лассуел наголошують, що символічний характер політичної комунікації проявляється в тому, що ізольовані агенти спроможні конституюватися як політична група тим міцніше, чим більше вони поєднанні на символічному рівні. Г. Лассуел узагалі наголошував, що головним предметом політичної науки має бути саме політична комунікація, що включає індоктринацію, агітацію та політичну символіку [11, с. 269]. Управління символами контекстуально постає як процес пошуку динамічних соціальних топосів, де $є$ бажаним інноваційний розвиток, який генерується істотним суспільним резонансом. Потенціал символічного управління співвідноситься в цій ситуації із властивостями соціальної спільноти. Символічне управління політичними трансформаціями являє собою технологію використання стимулювання символічних інновацій в умовах системи, у якій порушена структурна рівновага [14, с. 180].

Отже, варто концептуалізувати кінцевий потенціал інститутів у відтворенні політичного порядку. По-перше, політичний порядок - це сукупність соціальних мікропорядків, що відображають модель взаємодії, комунікації, обмежень, правил гри, що впорядковують характер діяль- ності соціальних агентів у певному соціальному просторі (не обов'язково територіально окресленому).

По-друге, соціальна реальність, у межах якої відбувається відтворення соціального та політичного порядку, - це насамперед інституційна реальність, яка іманентно є інструментом, механізмом забезпечення порядку. Оскільки інститути є організаційними, нормативно ціннісними (формальними/неформальними) структурами, що визначають специфіку відтворення моделей поведінки, правил, норм i процедур, забезпечують політичний порядок, вони є водночас і цілю, і засобом для утвердження соціального та політичного порядку.

По-третє, варто наголосити на коеволюційності процесів формування інституційного середовища (як інтегрованої сукупності формальних і неформальних інститутів) та комунікативної мережі соціальної системи. Коректніше було $б$ додати, що конструювання ефективної інституційної системи залежить від рівня розвитку комунікативного потенціалу суспільства, як-от: модель комунікації (вертикальна/горизонтальна), відкритість/закритість інформаційної мережі, рівень контрольованості/свободи інформаційного обміну. Водночас стиль, формат і модель комунікації жорстко зумовлені соціокультурними, ментальними, історичними та ціннісними аспектами окремо взятої соціальної спільноти, розуміння яких відкриває «опцію керування» символічними елементами (матеріальними та метафізичними) соціальної системи.

\section{Jimepamypa:}

1. Большева О. Концепция социального порядка в современной социологии. Армавир, 2004. С. 24-27.

2. Бунецький Л. Інституціональна проблематика в сучасній політичній науці: аналіз феномену «політичний інститут». Вісник Львівського університету. Серія «Філософсько-політологічні студіï». 2011. Вип. 1. С. 140-148. URL: http://nbuv.gov.ua/UJRN/ Vlu_fps_2011_1_16.

3. Бунецький Л. Інституційний дизайн сучасної української політики: криза ідентичності та конфлікт інтересів. Вісник Севастопольського наиіонального технічного університету. Серія «Політологія». 2013. Вип. 145. С. 120-136.

4. Бунецький Л. Інституційні інновації періоду демократичного транзиту України. Вісник Київського національного університету ім. Т. Шевченка. Київ : КНУ, 1958. Вип. 97 : Філософія. Політологія. 2010. С. 42-47.

5. Володенков С. Коммуникационные основы современного политического управления. Известия Саратовского университета. Серия «Социология. Политология». 2011. Т. 11. № 3. С. 74-78.

6. Грачев М. Политическая коммуникация: понятие, сущность. Политическая коммуникативистика : теория, методология $u$ практика / под ред. Л. Тимофеевой. Москва : Российская ассоциация политической науки (РАПН) ; Российская политическая энциклопедия (РОССПЭН), 2012. С. 77-90.

7. Гриценко А. Институциональная архитектоника : Предмет, основные законы, методология. Наукові праиі Донещького державного наиіонального технічного університету. Серія «Економічна». 2006. № 01. Вип. 103-1. С. 31- 37.

8. Дзялошинский И. Коммуникационные процессы в обществе: институты и субъекты : монография. Москва : Издательство АПК и ППРО, 2012. 592 c.

9. Зайцев А. Делиберативная демократия, диалог и их место в констелляции дискурса публичной политики. Научные ведомости Белгородского государственного университета. Серия «История. 
Политология. Экономика. Информатика». 2013. № 15 (158). Вып. 27. C. $147-153$.

10. Зайцев А. Проблемы институционализации политического диалога государства и гражданского общества. Известия высших учебных заведений. Поволжский регион. Общественные науки. 2011. № 2 (18). С. 27-36.

11. Мамонтова Е. Символ та символічне у сучасному політологічному дискурсі. Вісник Дніпропетровського університету. Серія «Філософія. Соціологія. Політологія». 2012. Т. 20. Вип. 22 (4). С. 267-272. URL: http://nbuv.gov.ua/UJRN/vdufsp_2012_20_22\%284\%29_54.

12. Пастернак Т. Основні підходи до аналізу інституційного дискурсу у сучасній лінгвістиці : методологічний аспект. Науковий вісник Східноєвропейського національного університету імені Лесі Украӥнки. 2011. № 6. С. 195-199.

13. Цуциева М. Политический дискурс как интегративный феномен. Вестник Ленинградского государственного университета им. А.С. Пушкина. 2012. № 2. С. 174-179.

14. Шиманова О. Теоретичні основи дослідження політичної комунікації. Украӥнська національна ідея: реалії та перспективи розвитку : збірник наукових праць. Львів, 2007. Вип. 19. С. 179-184.

Liasota A. Functional aspects of political institutions in the context of the organization of the political order

Summary. The article deals with the actual problem of institutionalization and organization of political order in democratic societies. According to the author, the formation of an independent Ukraine, further national and state construction faced the problem of low functional capacity of institutions, their inability to solve pressing social, economic and strategic issues; or lack of institutions in general. To date, the issue of constructing effective, stable political institutions has not been resolved. Accordingly, the author concludes that rethinking theoretical scientific and expert opinion, analyzing the practical manifestation of institutions in political reality is an important component of enhancing the capabilities and potential of institutions in Ukraine. This process requires the development and implementation of effective analytical tools.

The urgency of the work is to formulate new scientific views on the manifestation of institutional aspects of the political sphere. As the institutional component of the political system is the system-forming context of the functioning of the society and the production of political processes is actualized: first, the question of the study of the evolution of the theoretical basis of institutional theory; second, the specification of the applied aspects of institutionalism, the formation of which is conditioned by the evolution of the institutional environment.

The updating of the institutional aspects of the political sphere in the last few decades, including, has contributed to the need to design innovations, concepts and models of optimization, and to reform the political systems of the newly formed democracies. Accordingly, intellectual design in the political sphere has become directly linked to the process of institutional design and construction. In the research field of scientists, experts and politicians, the question of forming an effective, dynamic, democratic-oriented political process of a system capable of adapting to the changing environment of the environment has arisen.

Key words: political institutions, political order, political communication. 